\title{
MINDFUL PARENTING AND BEHAVIOURAL PROBLEMS IN PRESCHOOL CHILDREN
}

\author{
TONI MAGLICA ${ }^{1}$, INA REIĆ ERCEGOVAC ${ }^{1}$, MAJA LJUBETIĆ ${ }^{1}$ \\ ${ }^{1}$ Faculty of Humanities and Social Sciences, University of Split, Split, Croatia
}

Submitted: 17.10.19.

Original scientific paper

Accepted: 21.05.2020.

UDC: $159.922 .7: 373.2-055.52$

doi: $10.31299 /$ hrri.56.1.4

\begin{abstract}
The aim of this research was to find out if mindful parenting contributes to internalised and externalised problems in preschool children. A total of 168 mothers, fathers and preschool teachers took part in the research, which assesses the extent of internalised and externalised problems in 76 preschool children. Additionally, both parents completed the Mindfulness in Parenting Questionnaire. Results showed that internalised and externalised problems were significantly correlated, with externalised problems being more prominent in boys. Mothers and fathers differed only in one aspect of mindful parenting, empathic understanding for the child, which was higher in mothers. When analysing differences in mindful parenting of boys/girls, the results showed that fathers of boys have higher parental awareness than fathers of girls, while there were no other significant differences. Mindful parenting did not prove significant in predicting internalised problems of preschool children. In contrast, the results showed that $30 \%$ of externalised problems in children can be explained by the child's gender and by mindful parenting from both parents. These findings point to some differences between mothers and fathers contributing to externalised problems. Specifically, the father's focusing attention on the child with acceptance and the mother's self-efficacy were related to lower externalising problems, while the father's empathic understanding of the child and mother's non-reactivity were related to more externalising problems in children. The results are discussed in the context of existing knowledge about implicit parenting and child development outcomes.
\end{abstract}

Keywords: internalised and externalised problems, preschool age, mindful parenting

\section{INTRODUCTION}

Behavioural problems in early childhood and preschool-aged children are becoming the focus of practitioners and researchers. Worldwide research indicates that $9-12 \%$ of children of preschool age and earlier manifest different forms of emotional and behavioural problems (Benedict, Horner, \& Squires, 2007; Egger \& Angold, 2006; Lavigne et al., 1996), and among that population is a growing number of those manifesting specific psychiatric syndromes (Egger \& Angold, 2006; Keenan, Wakschlag \& Danis, 2007; Wichstrom \& BergNilesen, 2014). Research on behavioural problems in early childhood and preschool children is rare in Croatia, but parental assessments indicate that $10.3 \%$ of children have symptoms of a psychological disorder and are at risk of developing some form of psychiatric disorder (Boričević Maršanić, Zečević, Paradžik, \& Karapetrić Bolfan, 2017). Among five-year-olds, the prevalence of emotional disorders is 4.4\%; behavioural problems, $9.6 \%$; and ADHD, 8.0\% (Boričević Maršanić et al., 2017).

Investigating behavioural problems in the early years is of great importance for early detection and securing timely and appropriate interventions with children and their families. When not treated in time, early behavioural and emotional problems often persist and can be related to later school and relationship problems (Fallucco, Robertson Blackmore, Bejarano, Wysocki, Kozikowski, \& Gleason, 2016). Even short-term problems in childhood can endanger the child's natural development and learning; the child has difficulty solving key developmental tasks at a specific age (Živčić Bećirević, Smojver-Ažić, \& Mišćenić, 2003). What also needs to be taken care of is classification of symptoms, given that behavioural problems are often "disguised" by common developmental changes. Macuka (2008) states that maturation processes affect how symptoms are expressed, thus making them harder to recognise and treat on time. 
Detection of behavioural problems in early childhood and preschool children also depends on the assessment method. Thus scientists suggest assessing the child's behaviour from multiple sources and contexts, especially by parents and another adult (Achenbach, McConaughy, \& Howell, 1987; De Los Reyes \& Kazdin, 2005). As for the assessment of the child's internalised and externalised problems, Živčić-Bećirević et al. (2003) argue that assessments from parents and kindergarten teachers correlate significantly, although moderately, on all scales. Achenbach et al. (1987) found a greater agreement between adults from the same context (fathers and mothers) than between assessors from different contexts (mother and teacher).

Regardless of who is making the assessment, studies have shown that boys manifest more symptoms than girls (Gustafsson, ProczkowskaBjorklund, \& Gustafsson, 2017; Klein, Otto, Fuchs, Zenger, \& von Klitzing 2013), especially symptoms of externalising problems (Abdi, 2010; Jun-Li Chen, 2008; Živčić-Bećirević et al., 2003). However, growing research points to co-occurrence of internalising and externalising symptoms in children, even adolescents and adults (Angold, Costello, \& Erkanli, 1999; Cosgrove et al., 2011)

Researching the aetiology of behavioural problems, especially in preschool children, inevitably leads to testing different parenting characteristics that negatively affect developmental outcomes in children. The literature recognises these characteristics as "family risk factors". Risk factors are features and dangers present in an individual and/ or surroundings that have a higher probability of predicting the development of behavioural problems (Mrazek \& Haggerty, 1994). Starting from the premise that parents are the most important socialisers of a child's behaviour at preschool ages and that parenting practices have an important role in developing child's externalising or/and internalising problems (Aunola \& Nurmi, 2005; Granic \& Patterson, 2006; Parent, McKee, Rough, \& Forehand, 2016; Rohner \& Britner, 2002), the present study focuses on mindful parenting as a potential predictor of internalised and externalised problems of preschool-aged children.
Mindful parenting is a contemporary concept based on mindfulness, which is a metacognitive attention process that includes focusing on the "here and now" and on a non-judgmental acceptance of personal thoughts and feelings. It was conceptualised by Duncan and associates (Duncan, 2007; Duncan, Coatsworth \& Greenberg, 2009) as a multi-dimensional construct that includes listening with attention, non-judgmental acceptance of self and the child, self-regulation in parenting and empathy for oneself and the child. Listening with attention helps understand the child's verbal messages. Acceptance refers to establishing a balance among the goals of the child, the parent and interaction between the two. Acceptance also refers to acceptance of the child's characteristics. Emotional awareness means being sensitive to one's own and the child's emotional needs. Self-regulation implies emotional regulation in parent behaviour, while empathy for oneself and the child means more positive affection in the child-parent interaction, as well as an understanding of one's own parental efforts (Duncan et al., 2009). Mindful parenting means dedicated and committed parenting as opposed to superficial and "automatic" parenting, where parents are unaware of their own and their child's feelings and, often, of the child's behaviour (Ljubetić, Reić Ercegovac \& Mandarić, 2018).

Although mindful parenting is a relatively new construct and research exploring the effects of mindful parenting on child developmental outcomes is rare, there have been several attempts to explore whether mindful parenting contributes to positive outcomes in children. That research has focused mostly on adolescents, showing that mindful parenting has positive effects on parent-adolescent interaction (Coatsworth, Duncan, Greenberg, \& Nix, 2010; Lippold, Duncan, Coatsworth, Nix, \& Greenberg, 2015) or adolescent psychological well-being (Moreira, Gouveia \& Canavarro, 2018). One study testing a model delineating the indirect influence of parent dispositional mindfulness on parenting and youth psychosocial well-being (Parent et al., 2016) showed that in the subsample of parents of preschool-aged children (3-7), mindful parenting was directly related to positive and negative parental practices. Negative practices were then related to internalising and externalis- 
ing behavioural problems, while positive practices were related only to internalising, but not externalising, problems in children (Parent et al., 2016). A recent study by Corthorn (2018) showed that mindfulness-based interventions increase mindful parenting and reduce parental stress in mothers of preschool-aged children (Corthorn, 2018). Bogles, Lehtonen \& Restifo (2010, according to McCaffrey, 2015) also noted that mindful parenting positively affects the parent-child interaction through several mechanisms, including reducing parental stress. In a sample of mothers of 4-year olds, mindful parenting, together with maternal general anxiety, mediated the relationship between maternal anxiety during pregnancy and child internalising problems at age 4 (Henrichs, van den Heuvel, Witteveen, Wilschut, \& van den Bergh, 2019).

\section{RESEARCH AIMS AND HYPOTHESIS}

Because the role of mindful parenting in parenting practice and developmental outcomes in early childhood has yet to be discovered, the goal of this research was to examine the relationship between mindful parenting and the extent of internalised and externalised problems of preschool children. For that purpose, we first tried to answer several research questions including gender differences. Specifically, we tested for gender differences in internalised and externalised problems in preschool-aged children, gender differences between mothers and fathers in mindful parenting and differences between parents of boys and girls in mindful parenting. Finally, we tested whether mindful parenting of mothers and fathers can predict the extent of internalised and externalised problems in children.

It was expected that internalised and externalised problems would moderately correlate with gender, with boys showing more externalised problems than girls. Considering parents, it was expected that mothers would show higher mindfulness in parenting, as suggested by Medeiros, Gouveia, Canavarro, \& Moreira (2016) based on a sample of parents of children aged 8-19. Furthermore, since mothers are usually more sensitive and responsive to a child's needs (Medeiros et al., 2016; Parent et al., 2016), as well as more accepting than fathers (Chung, Zappulla, \& Kaspar, 2008; Dwairy, 2010), and since earlier research showed that women have higher mindfulness than men (Sturgess, 2012), it was expected that mothers would be more mindful in parenting, compared to fathers. Finally, since mindfulness in parenting was shown to be an important predictor of parental practices (Parent et al., 2016), it was assumed that mindful parenting would contribute to less internalised and externalised problems in children.

\section{MATERIALS AND METHODS}

\section{Sample}

A total of 168 participants assessed the behaviour of 76 children. For each child, the assessment was made by the mother $(\mathrm{N}=76)$, the father $(\mathrm{N}=76)$ and the teacher $(\mathrm{N}=16)$. One teacher assessed a maximum of five children. The children were between the ages 5 and $6(\mathrm{M}=5.81, \mathrm{SD}=0.55)$ and had been attending a preschool institution for at least a year by the time the assessment started $(\mathrm{M}=3.06, \mathrm{SD}=0.98)$. The behaviour of $\mathrm{N}=42$ boys and $\mathrm{N}=34$ girls was assessed. The mean age of the mother was $\mathrm{M}=35.43(\mathrm{SD}=4.80$, range $24-47)$, and of the father $\mathrm{M}=38.21$ ( $\mathrm{SD}=5.55$, range 25-55). There were $15.8 \%$ of parents with one child in the family, $56.58 \%$ with two children and $27.64 \%$ with three or more children in the family. About one-third of mothers had a high school education (30.67\%), 20\% had a vocational college degree, and the majority $(49.3 \%)$ had a university degree. Among fathers, $60.53 \%$ had a high school education, $14.47 \%$ had a vocational college degree and $23.7 \%$ had a university degree.

\section{Instruments}

The shortened Questionnaire for Examining Internalised and Externalised Problems of Preschool-aged children (Achenbach \& Rescorla, 2000; Achenbach, 1992; Brajša Žganec, 2002; Glibota, 2017) consists of 26 items that test how frequently different internalised behaviours (e.g. "he is reserved", "he keeps things to himself") and externalised behaviours (e.g. "he/she destroys his/ her things") appear in the previous six months on a scale of three points.

The original Mindfulness in Parenting Questionnaire (McCaffrey, 2015), for parents of chil- 
Hrvatska revija za rehabilitacijska istraživanja 2020, Vol 56, br. 1, str. 44-57

Table 1. Descriptive parameters on subscales of the Mindfulness in Parenting Questionnaire in subsamples of mothers and fathers

\begin{tabular}{|l|l|c|c|c|c|c|c|c|}
\hline Subscale & Parent & M & SD & Range & Cronbach $\alpha$ & N & Skewness & Kurtosis \\
\hline \multirow{2}{*}{$\begin{array}{l}\text { Focusing attention on a child } \\
\text { with acceptance }\end{array}$} & mother & 36.27 & 3.01 & $28-42$ & .63 & 9 & -.61 & .45 \\
\cline { 2 - 9 } & father & 35.82 & 3.75 & $27-44$ & .75 & 9 & .04 & -.26 \\
\hline \multirow{2}{*}{$\begin{array}{l}\text { Empathic understanding of } \\
\text { the child }\end{array}$} & mother & 16.39 & 1.57 & $12-19$ & .61 & 4 & -.60 & .41 \\
\cline { 2 - 9 } & father & 15.46 & 2.16 & $8-20$ & .72 & 4 & -.57 & .93 \\
\hline \multirow{2}{*}{ Parental self-efficacy } & mother & 19.24 & 2.22 & $12-25$ & .64 & 5 & -.04 & 1.00 \\
\cline { 2 - 9 } & father & 19.55 & 2.43 & $14-25$ & .71 & 5 & -.16 & .11 \\
\hline \multirow{2}{*}{ Parental awareness } & mother & 23.05 & 2.89 & $13-30$ & .67 & 6 & -.41 & 1.67 \\
\cline { 2 - 9 } & father & 23.15 & 2.78 & $14-29$ & .64 & 6 & -.52 & .83 \\
\hline \multirow{2}{*}{ Non-reactivity } & mother & 14.78 & 2.18 & $9-20$ & .73 & 4 & -.48 & .03 \\
\cline { 2 - 9 } & father & 14.66 & 2.39 & $7-19$ & .79 & 4 & -.22 & .18 \\
\hline
\end{tabular}

$N=$ number of items

dren aged 2-16, consists of 28 items that refer to different aspects of mindfulness in parenting (Duncan et al., 2009; de Bruin et al., 2012; McCaffrey, 2015). A translated and validated Croatian version of the questionnaire (Reić Ercegovac \& Ljubetić, 2019) was applied. The participants had to assess, using a 5 -point scale, how often they experienced the mentioned behaviours and experiences $(1=$ never, $5=$ always). The author of the original questionnaire used in this research suggests deriving two overall results, one including items directed at the parent (Parenting self-efficacy); and the other, including items directed at the child (Being in the moment with the child). Nevertheless, earlier implementation of this questionnaire on our samples pointed to a multifactorial structure (Reić Ercegovac \& Ljubetić, 2019), similar to what other authors suggest during the conceptualisation of mindful parenting (de Bruin et al., 2012; Duncan et al., 2009). Therefore, the present study used a five-factor structure found in a sample of over 500 parents (Reić Ercegovac \& Ljubetić, 2019). The factors included Focusing attention on the child with acceptance (e.g. "... did you actively bring your attention back to your child when you noticed you had become distracted?"), Empathic understanding of the child (e.g. “... could you tell how your child felt by looking at him/her"?), Parental self-efficacy (e.g. “...did you feel confident in your ability to handle difficult parenting situations"), Parental awareness (e.g. "...did you consider your feelings before disciplining your child?"), and Non-reactivity (e.g. "... did you take a moment to think before punishing your child?"). Although reliability parameters were somewhat lower than expected, especially in the subsample of mothers, they were still acceptable for research purposes (Table 1).

\section{Procedure}

The study was conducted in cooperation with two preschool institutions in the urban area. At a meeting held in the preschool institutions, parents were introduced to the content of the research and were asked to participate. After the procedure was explained to them, parents who agreed to participate signed informed consent and received questionnaires with instructions in the envelope. They were asked to assess the child's behaviour and their parenting with respect to that particular kind, regardless of any other children they may have. Questionnaires for mother, father, and preschool teacher were coded so that all of the data for one child could be matched. Ultimately, 76 complete sets of questionnaires were collected, one each from the mother, father and preschool teacher.

The data were analysed using the statistical application STATISTICA 13. Since almost all parental measures had skewness and kurtosis coefficients that ranged from -1 to +1 (Table 3 ), parametric tests were applied in the data analysis (Gravetter \& Wallnau, 2014).

\section{RESULTS}

At the very beginning, correlations among assessments by mothers, fathers, and teachers were calculated for all 26 behaviours. Significant cor- 
Table 2. Correlation coefficients among assessments by mothers, fathers and teachers and factor structure of the results formed

\begin{tabular}{|c|c|c|c|c|c|}
\hline & r mother/father & r mother/ teacher & $r$ father/ teacher & internalised & externalised \\
\hline Item 1 & $.56^{*}$ & $.48^{*}$ & .19 & & \\
\hline Item 2 & $.23 *$ & .07 & $.30 *$ & & \\
\hline Item 3 & $.53 *$ & .07 & .03 & & \\
\hline Item 4 & $.55^{*}$ & $.36^{*}$ & $.34 *$ & .73 & .16 \\
\hline Item 5 & $.49^{*}$ & .20 & $.27^{*}$ & & \\
\hline Item 6 & $.41 *$ & $.31 *$ & $.27 *$ & .28 & .67 \\
\hline Item 7 & $.52 *$ & $.25^{*}$ & $.29 *$ & .24 & .46 \\
\hline Item 8 & $.74 *$ & $.46^{*}$ & $.53 *$ & .01 & .85 \\
\hline Item 9 & $.35^{*}$ & .07 & .17 & & \\
\hline Item 10 & $.77 *$ & $.57 *$ & $.37 *$ & .72 & .35 \\
\hline Item 11 & $.63^{*}$ & $.24^{*}$ & $.24 *$ & & \\
\hline Item 12 & $.73^{*}$ & $.41 *$ & $.37 *$ & .84 & .07 \\
\hline Item 13 & $.52 *$ & $.29 *$ & $.48^{*}$ & .74 & .28 \\
\hline Item 14 & $.61^{*}$ & $.53 *$ & $.44^{*}$ & .82 & .01 \\
\hline Item 15 & $.49^{*}$ & $.44^{*}$ & .22 & & \\
\hline Item 16 & $.53^{*}$ & $.38^{*}$ & $.38^{*}$ & .02 & .78 \\
\hline Item 17 & $.25 *$ & .17 & .19 & & \\
\hline Item 18 & $.50 *$ & $.34 *$ & $.59 *$ & .11 & .68 \\
\hline Item 19 & $.58 *$ & $.26^{*}$ & $.28 *$ & .55 & .04 \\
\hline Item 20 & $.46^{*}$ & $.47 *$ & $.44^{*}$ & .72 & .12 \\
\hline Item 21 & $.68^{*}$ & $.38 *$ & $.27 *$ & .81 & .29 \\
\hline Item 22 & $.51^{*}$ & .05 & $.24^{*}$ & & \\
\hline Item 23 & $.65^{*}$ & $.30 *$ & $.41 *$ & .03 & .85 \\
\hline Item 24 & $.50 *$ & .15 & .14 & & \\
\hline Item 25 & $.62 *$ & $.24 *$ & $.36^{*}$ & .22 & .48 \\
\hline Item 26 & $.53 *$ & $.27 *$ & $.30 *$ & .84 & .31 \\
\hline \multicolumn{4}{|c|}{$\%$ explained variance } & $33 \%$ & $24 \%$ \\
\hline \multicolumn{4}{|c|}{$\begin{array}{|cc|} & M(s d)\end{array}$} & $13.41(4.42)$ & $11.13(3.25)$ \\
\hline \multicolumn{4}{|r|}{ Range } & $9-27$ & $7-22$ \\
\hline \multicolumn{4}{|r|}{ Cronbach $\alpha$} & .91 & .83 \\
\hline \multicolumn{4}{|c|}{ Average inter-item correlation } & .56 & .42 \\
\hline \multicolumn{4}{|r|}{ Skewness } & 1.56 & .94 \\
\hline \multicolumn{4}{|r|}{ Kurtosis } & 2.26 & .39 \\
\hline
\end{tabular}

${ }^{*} p<.05$

relations were observed between the assessments by mothers and teachers for 19 behaviours, and between assessments by fathers and teachers for 20 behaviours. Correlations were stronger for parents than in teacher-parent dyads, which is in line with earlier research (Achenbach et al., 1987, ŽivčićBećirević et al., 2003). To form a mean result for each child based on three assessments, only the behaviours that proved to have a significant correlation were taken into consideration (Table 1). In accordance with the suggestion of Achenbach (1987) to perform mean assessments only when moderate correlations were present, 17 mean results (behaviours) were formed for each child. These results were analysed using exploratory factor analysis (principal component method, varimax rotation). The obtained factor structure (Table 1) was relatively clear, with a high item saturation on one of the factors, and a low item saturation on the other, except for one item that had significant, high saturation on both factors and was left out from further analysis. Two composite results were formed, one for the internalised and one for the externalised problems. 
Table 3. Differences in the extent to which boys and girls demonstrated internalised and externalised problems

\begin{tabular}{|l|c|c|c|c|c|c|}
\hline \multirow{2}{*}{ Problem type } & \multicolumn{2}{|c|}{ Boys (N=42) } & \multicolumn{2}{|c|}{ Girls (N=34) } & \multirow{2}{*}{ t } & \multirow{2}{*}{ p } \\
\cline { 2 - 5 } & $\mathbf{M}$ & $\mathbf{s d}$ & $\mathbf{M}$ & $\mathbf{s d}$ & & .267 \\
\hline Internalised & 1.64 & .50 & 1.52 & .41 & 1.12 & .022 \\
\hline Externalised & 1.60 & .56 & 1.35 & .35 & 2.34 & .35 \\
\hline
\end{tabular}

Table 4. Differences and correlations in mindful parenting between mothers and fathers

\begin{tabular}{|c|c|c|c|c|c|}
\hline & & $\mathbf{M}$ & SD & $t(d f=75)$ & $\mathbf{r}$ \\
\hline \multirow{2}{*}{$\begin{array}{l}\text { Focusing attention on a child with } \\
\text { acceptance }\end{array}$} & mother & 4.03 & .33 & \multirow[t]{2}{*}{.88} & \multirow[t]{2}{*}{.14} \\
\hline & father & 3.98 & .42 & & \\
\hline \multirow{2}{*}{$\begin{array}{l}\text { Empathic understanding of the } \\
\text { child }\end{array}$} & mother & 4.10 & .40 & \multirow[t]{2}{*}{$3.21 *$} & \multirow[t]{2}{*}{.12} \\
\hline & father & 3.86 & .54 & & \\
\hline \multirow[t]{2}{*}{ Parental self-efficacy } & mother & 3.85 & .44 & \multirow[t]{2}{*}{-.97} & \multirow[t]{2}{*}{$.31 *$} \\
\hline & father & 3.91 & .49 & & \\
\hline \multirow[t]{2}{*}{ Parental awareness } & mother & 3.84 & .48 & \multirow[t]{2}{*}{-.23} & \multirow[t]{2}{*}{.16} \\
\hline & father & 3.86 & .46 & & \\
\hline \multirow[t]{2}{*}{ Non-reactivity } & mother & 3.70 & .55 & \multirow[t]{2}{*}{.42} & \multirow[t]{2}{*}{$.33 *$} \\
\hline & father & 3.66 & .60 & & \\
\hline
\end{tabular}

${ }^{*} p<.05$

Table 5. Differences in mindful parenting depending on the child's gender

\begin{tabular}{|l|l|c|c|c|c|c|}
\hline \multicolumn{2}{|c|}{} & Mboys & SDboys & Mgirls & SDgirls & t (df=74) \\
\hline \multirow{2}{*}{$\begin{array}{l}\text { Focusing attention on a child with } \\
\text { acceptance }\end{array}$} & mother & 4.00 & .35 & 4.07 & .32 & .99 \\
\cline { 2 - 7 } & father & 4.03 & .44 & 3.92 & .38 & -1.09 \\
\hline \multirow{2}{*}{$\begin{array}{l}\text { Empathic understanding of the } \\
\text { child }\end{array}$} & mother & 4.13 & .36 & 4.05 & .44 & -.89 \\
\cline { 2 - 8 } Parental self-efficacy & father & 3.95 & .59 & 3.76 & .46 & -1.49 \\
\hline \multirow{2}{*}{ Parental awareness } & mother & 3.90 & .42 & 3.78 & .47 & -1.17 \\
\cline { 2 - 8 } & father & 3.95 & .53 & 3.86 & .43 & -.74 \\
\hline \multirow{2}{*}{ Non-reactivity } & mother & 3.87 & .43 & 3.81 & .54 & -.53 \\
\cline { 2 - 8 } & father & 3.96 & .43 & 3.73 & .48 & $-2.16^{*}$ \\
\hline
\end{tabular}

$* p<.05$

Furthermore, to explore the association between the extent of internalised and externalised problems in children, Pearson's correlation coefficient was calculated $(\mathrm{r}=.40 ; \mathrm{p}<.05)$. It indicated a significant moderate relation, thus confirming the initial hypothesis. To examine whether boys and girls differed in externalised and internalised problems, two t-tests for independent samples were calculated (Table 3). There were no significant differences in the extent to which boys and girls demonstrated internalised problems, while externalised problems were more prominent in boys.

With the aim of comparison of mothers and fathers on the parenting measures, a series of t-tests for dependent samples were calculated (Table 4). Contrary to the hypothesis, the difference was noted only in one variable, i.e. empathic understanding for the child, with mothers being more empathic than fathers. Significant correlations between mother-father dyads were obtained for parental self-efficacy and non-reactivity.

To find out whether parents differ in mindful parenting depending on the child's gender, a series of t-tests with the child's gender as an independent variable were calculated, and the results are presented in Table 5 . There was only one significant difference: fathers reported greater parental awareness of boys than girls. In all other cases, there 
Table 6. Stepwise forward regression analysis with externalised problems in children as the criterion (Step 5 final solution)

\begin{tabular}{|l|c|c|c|c|c|c|}
\hline Variables included in the model & VIF & Tolerance & $\boldsymbol{\beta}$ final step & $\mathbf{R}(\mathbf{R 2})$ & $\Delta \mathbf{R 2}$ & F (df) \\
\hline 1. Focusing attention on child with acceptance - father & 1.57 & .64 & $-.46^{* *}$ & $.27(.07)$ & $.07^{*}$ & $5.93^{*}(1,74)$ \\
\hline 2. Child's gender & 1.05 & .95 & $-.28^{* *}$ & $.41(.16)$ & $.09^{* *}$ & $7.15^{* *}(2,73)$ \\
\hline 3. Empathic understanding of the child - father & 1.53 & .66 & $.29^{* *}$ & $.46(.21)$ & $.05^{*}$ & $6.33^{* *}(3,72)$ \\
\hline 4. Non-reactivity - mother & 1.54 & .65 & $.36^{* *}$ & $.50(.25)$ & $.04^{*}$ & $5.79^{* *}(4,71)$ \\
\hline 5. Parental self-efficacy - mother & 1.57 & .64 & $-.30^{*}$ & $.55(.30)$ & $.06^{*}$ & $6.12^{* *}(5,70)$ \\
\hline
\end{tabular}

$* p<.05 ; * * p<.01$

were no differences between mindful parenting of boys or girls.

To address the last research problem and explore whether mindful parenting significantly contributes to child problems, regression analyses were made. Due to the relatively small sample and large number of predictors $(\mathrm{N}=11)$, a stepwise forward analysis was applied for both criterion variables, internalised and externalised problems. To test the potential problem of multi-collinearity, tolerance and variance inflation factors (VIF) were examined. Since tolerance larger than 0.2 and VIF below 5 are considered acceptable (Hair et al., 2010), two regression analyses were conducted. Contrary to expectations, analysis for internalised problems showed that none of the potential predictors reached significance; therefore, mindful parenting did not appear to be relevant for explaining children's internalising problems. Analysis with externalised problems as the criterion (Table 6) included 5 steps, and predictors accounted for $30 \%$ of the variance in externalised problems. This analysis also pointed to different contributions of mindful parenting facets to children's externalising problems. Contrary to expectations, the father's empathic understanding of the child and mother's non-reactivity were related to more externalising problems, while the father's focusing attention on the child with acceptance and the mother's self-efficacy were related to lower externalising problems.

\section{DISCUSSION}

Results revealed significant correlation between internalised and externalised problems in children, which supports the initial hypothesis and is in accordance with earlier research on samples of children and youth of different ages (Achenbach \& Rescorla, 2000; Angold, Costello, \& Erkanli, 1999;
Hammen \& Rudolph, 2003; Macuka \& SmojverAžić, 2012). A meta-analysis conducted by Angold et al. (1999) found statistically significant comorbidity of internalising (anxiety and depression) and externalising disorders (ADHD and conduct disorders/oppositional defiant disorder) in children and adolescents. Even among adults there is evidence of co-occurrence between internalising and externalising disorders (Kruger, 1999).

The findings in the present study also showed significant differences between boys and girls in externalised behaviour, where, as expected, boys showed more such behaviour. Similarly, earlier research also confirmed gender differences only in externalised problems, with boys exhibiting more externalising behaviour than girls (Gustafsson, Proczkowska-Bjorklund, \& Gustafsson, 2017; Klein, Otto, Fuchs, Zenger, \& von Klitzing 2013; Abdi, 2010; Jun-Li Chen, 2008; Živčić-Bećirević et al., 2003). Several authors pointed that although gender differences are not evident in the first few years, they start showing at age five (Lavigne et al., 1996; Rose, Rose, \& Feldman, 1989), which corresponds with the age of the children in our sample. Gender differences in externalising behaviour can be explained within several theoretical frameworks. As suggested by Hill, Degnan, Calkins, \& Keane (2006), boys, compared to girls, could be more socialised toward under-controlling behaviours. Boys are usually encouraged to higher-intensity playing activities (Maccoby, 1990; 1998), sports with physical contact and a higher level of competition, all of which can nurture more aggressive and under-controlled behaviour. Parents and teachers may assess externalising behaviours to be higher in boys since they prefer engaging in high-intensity activities that include more physical aggression, unlike girls who usually play in 
low-intensity activities (Else-Quest, Shibley Hyde, Goldsmith, \& Van Hulle, 2006, Maccoby, 1990; 1998). A longitudinal study by Flanders et al. (2010) showed a significant relationship between more frequent rough-and-tumble play with the father during childhood, which is more common for boys, and physical aggression. Furthermore, longitudinal research on large samples showed that childhood gender-typed play behaviour predicts physical aggression in early adolescence, with male-typical play behaviour during childhood increasing subsequent physical aggression (Kung, Golding \& Hines, 2018). Socialisation of more aggressive and under-controlled behaviours in boys compared to girls is probably related to temperamental gender differences in children that start showing in the early years. Indeed, gender differences in externalising behaviour may also arise from the child's temperament, mainly through differences in dimensions such as effortful control or surgency (Rohbart, 1981). Research on samples of toddlers and preschool-aged children showed a significant relationship between externalising problems and low effortful control (Murray \& Kochanska, 2002; Olson, Sameroff, Kerr, Lopez, \& Wellman, 2005). A meta-analysis of studies on gender differences in temperament (Else-Quest et al., 2006) showed consistent differences, with girls higher on effortful control by one standard deviation compared to boys. Boys, on the other hand, achieve higher scores on the surgency dimension. The same research showed that differences in effortful control were most notable in attention regulation and inhibitory control, which are related to externalising behaviours (Moffitt, 2003; Teichner \& Golden, 2000). It can be said that early-appearing gender differences in aspects of temperament, followed by different socialisation of controlled and under-controlled behaviour in boys and girls, leads to well-documented gender differences in externalising behaviours in children.

In exploring differences in mindful parenting between mothers and fathers, results showed a difference only in the empathic understanding of the child, which was higher for mothers. More empathy for the child by the mother can be observed in the context of a generally higher level of empathy in women (Rueckert \& Naybar, 2008), as well as a generally higher sensitivity and responsiveness of mothers to their children's needs (Medeiros et al., 2016; Parent et al., 2016).

Different parental roles were implied by the regression analysis, which tested the role of mindful parenting in explaining the extent of internalised and externalised problems in children. The indicated predictors from previous analyses proved more efficient in explaining externalised rather than internalised problems. It is possible that some other parental characteristics, characteristics of parent-child interactions or even a child's temperament, for instance, behavioural inhibition (Hastings, Helm, Mills, Serbin, Stack, \& Schwartzman, 2015) or negative emotionality (Davis, Votruba-Drzal, \& Silk, 2015), determine internalised difficulties more.

Analysis of externalising problems showed that mindful parenting has an important role in explaining the child's externalising problems. The father's focusing attention on the child with acceptance seems most important among the selected predictors. It is possible that focusing attention on the child means a better understanding of the child's messages and needs (Duncan et al., 2009), which contributes to reducing externalising problems. Also, directing attention to the child and focusing on father-child interaction may decrease the possibility that the child engages in externalising behaviours, which sometimes serve to attract the attention of adults. Therefore, if the father is more focused on the child and the child easily gets his full attention, the need for externalising behaviours may diminish. Furthermore, fathers who focus their attention on the child and show acceptance are probably more able to reflect upon their parental behaviours and children's responses to those behaviours, thus avoiding negative parental practices that increase the risk of a child's externalising behaviours (Parent et al., 2016).

According to regression analysis results, the father's focusing attention on the child with acceptance is followed by their empathic understanding for the child, mother's non-reactivity and maternal self-efficacy. These aspects of mindful parenting do not make similar contributions to the child's externalising behaviour. Children of fathers who focus more attention on the child while accepting them 
express less externalising behaviour, but a father's empathic understanding of the child is not beneficial for externalising behaviour. On the contrary, the results suggest that the more the father empathically understands the child, the more externalising behaviour the child exhibits. This result was unexpected, but it may have several explanations. When considering the items that make up this factor, it can be seen that they include a father's understanding of the child's signs and needs without any special interaction; in other words, a father feels he can understand what the child is thinking or feeling just by looking at him or her. It is possible that fathers who assessed themselves high on this factor overestimated their understanding of the child or in fact do not pay enough attention to interactions with the child, yet they still draw conclusions about the child's feelings and thoughts without real communication. Children of preschool age need real and concrete interaction with their parents, and in the absence of it, they may seek it with excessively uncontrolled behaviour that will provide them the desired attention from the father. In the absence of the possibility to communicate their thoughts, feelings, and needs in real father-child interaction, children can engage in more intrusive behaviours. Since this result was unexpected and does not fit into the concept of mindful parenting, it points to the need for a closer examination of the concept structure.

For mothers, the results indicate that higher non-reactivity and lower maternal self-efficacy relate to more externalising behaviour in children. Although non-reactivity is assumed to be beneficial according to the concept of mindful parenting, the results of this study suggest differently. As Duncan et al. (2009) noted, mindful parenting does not mean that parents do not feel angry or frustrated, but "involves pausing before reacting in parenting interactions in order to exercise greater self-regulation and choice in the selection of parenting practices" (Duncan et al., 2009, p. 260). It is possible that this pause can be effective in older children, particularly adolescents, but that it can cause frustration or insecurity in younger children given their cognitive and emotional abilities, especially if the child expects approval or praise. The reaction is probably the same when the child is behaving inappropriately. The child expects the mother's reaction immediately; otherwise, he or she feels the parent is disinterested or may experience fear of subsequent punishment. It is possible that by changing behaviour, the child is attempting to provoke a response from the mother. If the child is exposed to "a slow" response from the mother for longer periods, the child can start to increasingly draw attention to himself by expressing (externalised) behavioural difficulties. Since there are no data in the literature regarding the predictive value of non-reactivity as part of mindful parenting for the child's behaviour, and considering the results of the present study, the role of this feature of mindful parenting should be explored in future work.

As for maternal self-efficacy, the results confirm that lower self-efficacy in parenting contributes to more externalising behaviours. Earlier research pointed to the significant relationship between maternal perceived parenting self-efficacy and their actual parental competence and parenting skills (Coleman \& Karraker, 1998; Jones \& Prinz, 2005; Sanders \& Woolley, 2005). Furthermore, the authors found a positive correlation between reduced perceived parental self-efficacy and ineffective parental confrontation with a child's behavioural difficulties (Sevigny \& Loutzenhiser, 2010). The results of the current research also point to this relationship. Mothers who perceive themselves to be less effective in their parenting probably have fewer parenting skills needed for positive and desirable parenting practices, which may result in more externalised problems in children. On the other hand, mothers of children who have more externalising problems may often feel frustrated and ineffective in their parenting, which undermines their self-efficacy assessment.

\section{CONCLUSION}

Before concluding, it is necessary to look at the limitations of this research, which primarily relate to the modest sample of children assessed. Still, assessments of internalising and externalising children's problems were made by three of the most relevant adults, thus presenting a more objective measure than is usually used in similar research. Furthermore, since the construct of mindful parenting is relatively recent and insufficiently 
explored, including its construct validity, there is a need for a better understanding of its factors and for reviewing existing measures, some of which have shown marginal reliability in this research. Despite the shortcomings, the findings of this study confirm some of the initial assumptions regarding the relationship between parenting and behaviour of preschool-aged children, while also pointing to some new insights that should be further explored. For example, mindful parenting is a relevant pre- dictor of a child's externalised problems as early as in preschool age, which has so far been shown mainly in samples of adolescents. Finally, considering the indirect relationship between implicit parenting and child developmental outcomes, it would be important to explore how mindful parenting is mediated by actual parental behaviour and whether it affects child behaviour problems through parental practice. 


\section{REFERENCES}

Abdi, B. (2010). Gender differences in social skills, problem behaviors and academic competence of Iranian Kindergarten children based on their parent and teacher rating. Procedia-Social and Behavioral Sciences, 5, 1175-1179. doi: 10.1016/j.sbspro.2010.07.256.

Achenbach, T. M. (1992). Manual for child behavior checklist/2-3 and 1992 profile. Burlington, VT: University of Vermont.

Achenbach, T. M., \& Rescorla, L. A. (2000). Manual for the ASEBA preschool forms \& profiles. Burlington, VT: University of Vermont.

Achenbach, T. M., McConaughy, S. H., \& Howell, C. T. (1987). Child/adolescent behavioral and emotional problems: implications of cross-informant correlations for situational specificity. Psychology Bulletin, 101, 213-232.

Angold, A., Costello, E. J., \& Erkanli, A. (1999). Comorbidity. Journal of Child Psychology and Psychiatry and Applied Disciplines, 40(01), 57-87.

Aunola, K., \& Nurmi, J. (2005). The role of parenting styles in children's problem behavior. Child Development, 76(6), 1144-1159.

Benedict, E. A., Horner, H. H., \& Squires, J. K. (2007). Assessment and Implementation of positive behavior support in preschools. Topics in Early Childhood Special Education, 27, 74-193.

Boričević Maršanić, V., Zečević, I., Paradžik, Lj., \& Karapetrić Bolfan, Lj. (2017). Probir i rana detekcija psihičkih odstupanja/poremećaja kod djece u predškolskim ustanovama i adolescenata u osnovnim školama Grada Zagrebarezultati probnog projekta. Socijalna psihijatrija, 45(3), 169-186.

Brajša Žganec, A., \&. Vizek Vidović, V. (2002). Roditeljske metaemocije i socijalno-emocionalni razvoj djece. (Unpublished doctoral dissertation). University of Zagreb, Zagreb, Croatia.

Caspi, A. (2000). The child is father of the man. Personality continuities from childhood to adulthood. Journal of Personality and Social Psychology, 78(1), 158-172.

Chung J., Zappulla, C., \& Kaspar, V. (2008). Parental warmth and socio-emotional adjustment in Brazilian, Canadian, Chinese, and Italian children: A cross-cultural perspective. In Ricardo N. Ramirez (Ed.), Family relations, issues, and challenges (pp. 21-41). New York: Nova Science Publishers, Inc.

Coatsworth, J. D., Duncan, L. G., Greenberg, M. T., \& Nix, R. L. (2010). Changing parent's mindfulness, child management skills and relationship quality with their youth: Results from a randomized pilot intervention trial. Journal of Child and Family Studies, 19(2), 203-217.

Coleman, P. K., \& Karraker, K. H. (1998). Self-Efficacy and Parenting Quality: Findings and Future Applications. Developmental Review, 18(1), 47-85.

Corthorn, C. (2018). Benefits of Mindfulness for Parenting in Mothers of Preschoolers in Chile. Frontiers in Psychology, 9, 1443. doi: 10.3389/fpsyg.2018.01443.

Cosgrove, V. E., Rhee, S. H., Gelhorn, H. L., Gelhorn, H. L., Boeldt, D., Corley, R. C., Ehringer, M. A., Young, S. E., Hewitt, J. K. (2011). Journal of Abnormal Child Psychology, 39, 1, 109-123. doi: 10.1007/s10802-010-9444-8

Davis, S., Votruba-Drzal, E., \& Silk, J. S. (2015). Trajectories of Internalizing Symptoms from Early Childhood to Adolescence: Associations with Temperament and Parenting. Social Development, 24(3), 501-520. doi: https:// doi.org/10.1111/sode. 12105 .

De Bruin, E. I., Zijlstra, B. J. H., Geurtzen, N., van Zundert, R. M. P., van de Weijer- Bergsma, E., Hartman, E. E., Nieuwesteeg, A. M, Duncan, L. G, \& Bogles, S. M. (2012). Mindful parenting assessed further: Psychometric properties of the Dutch version of the Interpersonal Mindfulness in Parenting scale (IM-P). Mindfulness, 5(2), 200-212. doi: 10.1007/s12671-012-0168-4.

De Los Reyes, A., \& Kazdin, A. E. (2005). Measuring informant discrepancies in clinical child research. Psychological Assessment, 16, 330-334. doi: 10.1037/1040-3590.16.3.330. 
Hrvatska revija za rehabilitacijska istraživanja 2020, Vol 56, br. 1, str. 44-57

De Los Reyes, A., \& Kazdin, A. E. (2008). When the evidence says "Yes, no, and maybe so": Attending to interpreting inconsistent findings among evidence-based interventions. Current Directions in Psychology Science, 17, 47-51.

Duncan, L. G. (2007). Assessment of mindful parenting among parents of early adolescents: Development and validation of the Interpersonal Mindfulness in Parenting scale. (Unpublished doctoral dissertation). The Pennsylvania State University, Pennsylvania, USA.

Duncan, L. G., Coatsworth J. D., \& Greenberg, M. T. (2009). A model of mindful parenting: Implications for parentchild relationships and prevention research. Clinical Child \& Family Psychology Review, 12(3), 255-270. doi: 10.1007/s10567-009-0046-3.

Dwairy, M. (2010). Parental acceptance-rejection: A fourth cross-cultural research on parenting and psychological adjustment of children. Journal of Child and Family Studies, 19(1), 30-35.

Egger, H. L., \& Angold, A. (2006). Common emotional and behavioral disorders in preschool children: presentation, nosology, and epidemiology. Journal of Child Psychology and Psychiatry, and applied disciplines, 47(3-4), 313337. doi:10.1111/j.1469-7610.2006. 01618.x.

Else-Quest, N. M., Shibley Hyde, J., Goldsmith, H., \& Van Hulle, C. A. (2006). Gender Differences in Temperament: A Meta-Analysis. Psychological Bulletin, 132(1), 33-72.

Fallucco, E. M., Robertson Blackmore, E., Bejarano, C. M., Wysocki, T., Kozikowski, C. B., \& Gleason, M. M. (2016). Feasibility of screening for preschool behavioral and emotional problems in primary care using the early childhood screening assessment. Clinical paediatrics, 56(1), 37-45.

Flanders, J. L., Simard, M., Paquette, D., Parent, S., Vitaro, F., Pihl, R. O., \& Séguin, J. R. (2010). Rough-and-tumble play and the development of physical aggression and emotion regulation: A five-year follow-up study. Journal of Family Violence, 25, 357-367. doi: 10.1007/s10896-009-9297-5.

Glibota, P. (2017). Emocionalni razvoj djece rane i predškolske dobi-procjena roditelja. (Unpublished Master Thesis). Faculty of Humanities and Social Sciences, University of Split, Split, Croatia.

Granic, I., \& Patterson, G. R. (2006). Toward a comprehensive model of antisocial development: A dynamic systems approach. Psychological Review, 113, 101-131.

Gravetter, F., \& Wallnau, L. (2014). Essentials of statistics for the behavioral sciences (8th ed.). Belmont, CA: Wadsworth.

Gustafsson, B. M., Proczkowska-Björklund, M., Gustafsson, P. A. (2017). Emotional and Behavioural problems in Swedish preschool children rated by preschool teachers with Strengths and Difficulties Questionnaire (SDQ). BMC Paediatrics, 17,110. doi: 10.1186/s12887-017-0864-2

Hair, J. F., Black, W. C., Babin, B. J., Anderson, R. E., \& Tatham, R. L. (2010). Multivariate Data Analysis (7th ed). New York: Pearson.

Hammen, C., \& Rudolph, K. D. (2003). Childhood mood disorders. In E. J. Mash \& R. A. Barkleys (Eds.). Child Psychopathology (pp.233-278). New York: Guilford Press.

Hastings, P. D., Helm, J., Mills, R. S. L., Serbin, L. A., Stack, D. M., \& Schwartzman, A. E. (2015). Dispositional and environmental predictors of the development of internalizing problems in childhood: Testing a multilevel model. Journal of Abnormal Child Psychology, 43, 831-845. doi: http://dx.doi.org/10.1007/s10802-014-9951-0.

Henrichs, J., van den Heuvel, M. I., Witteveen, A. B., Wilschut, J., \& van den Bergh, B. R. H. (2019). Does Mindful Parenting Mediate the Association between Maternal Anxiety during Pregnancy and Child Behavioral/Emotional Problems? Mindfulness (2019). https://doi.org/10.1007/s12671-019-01115-9

Hill, A., Degnan, K., Calkins, S. D., \& Keane, S. P. (2006). Profiles of externalizing behavior problems for boys and girls across preschool: The roles of emotion regulation and inattention. Developmental Psychology, 42, 913-928.

Jones, T. L., \& Prinz, R. J. (2005). Potential roles of parental self-efficacy in parent and child adjustment: A review. Clinical Psychology Review, 25(3), 341-363. 
Jun-Li Chen, J. (2010). Gender differences in externalizing problems among preschool children: implications for early childhood educators. Early Child Development and Care, 180(4), 463-474. doi: 10.1080/03004430802041011.

Jurčević-Lozančić, A. (2005). Izazovi odrastanja-predškolsko dijete u okružju suvremene obitelji i vrtića. Petrinja: Visoka učiteljska škola u Petrinji.

Keenan, K., Wakschlag, L.S., \& Danis, B. (2007). Further evidence of the reliability and validity of DSM-IV ODD and CD in preschool children. Journal of the American Academy of Child and Adolescent Psychiatry, 46, 457-468.

Klein, A.M., Otto, Y., Fuchs, S., Zenger, M. \& von Klitzing, K. (2013). Psychometric properties of the parent-rated SDQ in pre-schoolers. European Journal of Psychological Assessment, 29 (2), 96-104. doi: 10.1027/1015-5759/a000129

Kung, K. T. F., Golding, L. G., \& Hines, M. (2018). Preschool Gender-Typed Play Behavior at Age 3.5 Years Predicts Physical Aggression at Age 13 Years. Archive of Sexual Behavior, 47(4), 905-914. doi: 10.1007/s10508-017-1005-6.

Lavigne, J. V., Gibbons, R. D., Christoffel, D., Arend, R., Rosenbaum, D., Binns, Dawson, N.,..., \& Isaacs, C. (1996). Prevalence rates and correlates of psychiatric disorders amongst preschool children. Journal of American Academy of Child and Adolescent Psychiatry 35, 204-214. doi: 10.1097/00004583-199602000-00014.

Lippold, M. A., Duncan, L. G., Coatsworth, J. D., Nix, R. L. \& Greenberg, M. T. (2015). Understanding how mindful parenting may be linked to mother-adolescent communication. Journal of Youth and Adolescence, 44, 1663-1673. doi:10.1007/ s10964-015-0325-x

Ljubetić, M., Reić Ercegovac, I. \& Mandarić Vukušić., A. (2018). Irresponsible/Unmindful Parenting: An Empire for the Media. In J. Lepičnik Vodopivec, L. Jančec, \& T. Štemberger (Eds.), Implicit Pedagogy for Optimized Learning in Contemporary Education (pp.270-289). USA: IGI Global.

Maccoby, E. E. (1990). Gender and relationships: A developmental account. American Psychologist, 45(4), 513-20. doi: 10.1037/0003-066X.45.4.513

Maccoby, E. E. (1998). The two sexes: Growing up apart, coming together. Cambridge, MA: Harvard University Press.

Macuka, I. (2008). Uloga dječje percepcije roditeljskoga ponašanja u objašnjenju internaliziranih i eksternaliziranih problema. Društvena istraživanja: časopis za opća društvena pitanja, 17, 1179-1202.

Macuka, I., \& Smojver-Ažić, S. (2012). Osobni i obiteljski čimbenici prilagodbe mlađih adolescenata. Hrvatska revija za rehabilitacijska istraživanja, 48(1), 27-43.

McCaffrey, S. (2015). Mindfulness in Parenting Questionnaire (MIPQ): Development and validation of a measure of mindful parenting. (Unpublished Doctoral Dissertation). Nova Southeastern University. Retrieved from https:// nsuworks.nova.edu/cps_stuetd/81.

Medeiros, C., Gouveia, M. J., Canavarro, M.C., \& Moreira, H. (2016). The indirect effect of the mindful parenting of mothers and fathers on the child's perceived well-being through the child's attachment to parents. Mindfulness, 7(4), 916-927. doi:10.1007/s12671-016-0530-z.

Moffitt, T. E. (2003). Life-course persistent and adolescence-limited antisocial behavior: A 10-year research review and a research agenda. In B. B. Lahey, T. E. Moffitt, \& A. Caspi (Eds.), Causes of conduct disorder and juvenile delinquency (pp. 49-75). New York: Guilford Press.

Moreira, H., Gouveia, M. J., \& Canavarro, M. C. (2018). Is mindful parenting associated with adolescents' wellbeing in early and middle/late adolescence? The mediating role of adolescents' attachment representations, selfcompassion and mindfulness. Journal of Youth and Adolescence, 47, 1771-1788.

Mrazek, P. J., \& Haggerty, R. J. (1994). Reducing Risk for Mental Disorders: Frontiers for Prevention Intervention Research. Washington DC: National Academy Press.

Murray, K. T., \& Kochanska, G. (2002). Effortful control: Factor structure and relation to externalizing and internalizing behaviors. Journal of Abnormal Child Psychology, 30, 503-514.

Olson, S. L., Sameroff, A. J., Kerr, D. C. R., Lopez, N. L., \& Wellman, H. M. (2005). Developmental foundations of externalizing problems in young children: The role of effortful control. Development and Psychopathology, 17, 25-45. doi: 10.10170S0954579405050029 
Parent, J., McKee, L. G., Rough, J. N., \& Forehand, R. (2016). The association of parent mindfulness with parenting and youth psychopathology across three developmental stages. Journal of Abnormal Child Psychology, 44, $191-202$. doi: $10.1007 / \mathrm{s} 10802-015-9978-\mathrm{x}$.

Reić Ercegovac, I., \& Ljubetić, M. (2019). Svjesnost u roditeljstvu majki i očeva djece različite dobi: Validacija hrvatske inačice upitnika. Psihologijske teme, 28(2), 397-418.

Rohbart, M. (1981). Development of individual differences in temperament. In: M.E. Lamb, \& A.L. Brown (Eds.), Advances in Developmental Psychology. Volume 1 (pp. 37-86). Hillsdale, New Jersey: Lawrence Erlbaum Associates.

Rohner, R. P., \& Britner, P. A. (2002). Worldwide mental health correlates of parental acceptance-rejection: Review of cross-cultural and intracultural evidence. Cross-Cultural Research, 36(1), 16-47.

Rose, S. L., Rose, S. A., \& Feldman, J. F. (1989). Stability of behavior problems in very young children. Development and Psychopathology, 1, 5-19. doi: 10.1017/S0954579400000213.

Rueckert, L., \& Naybar, N. (2008). Gender differences in empathy: The role of the right hemisphere. Brain and Cognition, 67, 162-167. doi: 10.1016/j.bandc.2008.01.002.

Sanders, M. R., \& Woolley, M. L. (2005). The relationship between maternal self-efficacy and parenting practices: implications for parent training. Child: Care, Health and Development, 31, 65-73.

Sevigny, P. R., \& Loutzenhiser, L. (2010.). Predictors of parenting self-efficacy in mothers and fathers of toddlers. Child: Care, Health, Development, 36, 179-189.

Sturgess, M. A. (2012). Psychometric validation and demographic differences in the two recently developed trait mindfulness measures. (Unpublished Master's Thesis). Victoria University of Wellington, Wellington, New Zealand.

Teichner, G., \& Golden, C. (2000). The relationship of neuropsychological impairment to conduct disorder in adolescence. Aggression and Violent Behavior, 5, 509-528.

Wichstrom, L., \& Berg-Nielsen, T. S. (2014). Psychiatric disorders in preschoolers: the structure of DSM-IV symptoms and profiles of comorbidity. European Child and Adolescent Psychiatry, 23(7), 551-562. doi: 10.1007/s00787013-0486-7.

Živčić-Bećirević, I., Smojver-Ažić, S., \& Mišćenić, G. (2003). Problemi u ponašanju djece predškolske dobi prema procjeni roditelja i odgojitelja. Psihologijske teme, 12, 63-76. 